\begin{tabular}{c} 
Volume and Issues Obtainable at Center for Sustainability Research and Consultancy \\
Journal of Business and Social Review in Emerging Economies \\
ISSN: 2519-089X \& ISSN (E): 2519-0326 \\
Volume 7: Issue 2 June 2021 \\
ᄃSR \\
Journal homepage: $\underline{\text { www.publishing.globalcsrc.org/jbsee }}$ \\
\hline
\end{tabular}

\title{
Framing of Kashmir Conflict in Elite Pakistani and Indian Newspapers after Revocation of Special Status of the Disputed Territory
}

*Ayesha Siddiqua, Lecturer Mass Communication in National University of Modern Languages, Islamabad, Pakistan

Atif Ashraf, Assistant Professor, Faculty of Media and Communication Studies, University of Central Punjab, Lahore, Pakistan

Ghulam Shabbir, Professor, Faculty of Media and Communication Studies, University of Central Punjab, Lahore, Pakistan

Qamaruddin Zia Ghaznavi, Assistant Professor, School of Media and Communication Studies, Beaconhouse National University, Lahore, Pakistan

*Corresponding author's email address: ayeshasiddiqua05@gmail.com

\section{ARTICLE DETAILS}

\section{History}

Revised format: May 2021

Available Online: Jun 2021

\section{Keywords}

Indian Constitution, Article 370, Kashmir Dispute, War and Peace Journalism India Pakistan

JEL Classification L82, H79

\begin{abstract}
Purpose: India, using its legislative powers, divided Jammu and Kashmir J\&K into two separate territories under federal control by revoking Article 370 that had given a special status to the disputed territory. This move stirred isolation and suppression in the people of the valley. The purpose of the study is to comprehend the peace and war framing of the Kashmir conflict after the revocation of the special status of the disputed territory in the Indian and Pakistani media. The study also attempts to explore the strategic relevance of Kashmir for neighboring China. Design/Methodology/Approach: Framing, Peace and War Journalism theories were used in this study. Quantitative content analysis method was used to analyze the peace and war framing of the J\&K conflict in Dawn and Times of India. Findings: Content analysis findings supported assumption that war coverage was the most highly recorded coverage pattern in both Indian and Pakistani newspapers. Dawn took a lead in peace journalism framing with $25.56 \%$ of its editorials and columns dominated with peace journalism frames whereas $11.88 \%$ editorials and columns in Times of India were dominated with peace journalism frames. Implications/Originality/Value: The study finds that Kashmir dispute was framed in War Journalism viewpoint in media of both the neighboring countries. This research also shows that Beijing sticks to its strategic guns by giving peaceful verbal gestures for the region's stability.
\end{abstract}

(C) 2021 The authors, under a Creative Commons AttributionNonCommercial 4.0

Recommended citation: Siddiqua, A., Ashraf, A., Shabbir, G. and Ghaznavi, Q. Z. (2021). Framing of Kashmir Conflict in Elite Pakistani and Indian Newspapers after Revocation of Special Status of the Disputed Territory. Journal of Business and Social Review in Emerging Economies, 7 (2), 291- 
300

\section{Introduction}

The magnitude of Kashmir conflict has evolved from a regional conflict to an international conflict as it enjoys the capability of drawing India and Pakistan towards a nuclear war (Nixon, 1992). Geographically Kashmir is surrounded by India, Pakistan and China. Kashmir is located in the Himalayan range of mountains and is also the origin point of many rivers in the South Asian region. India administers about 45 percent of Kashmir's total area; Pakistan administers about 35 percent of Kashmir's total area whereas China administers about 20 percent of Kashmir's total area (Bukhari \& Parveen, 2014). The Kashmir conflict although considered to be a concern for international peace has constantly given rise to ethnic outbreak, severe human rights violations and cross border terrorism including Line of Control violations in the region.

The year 2016 witnessed an intense violent atmosphere in the valley. Shortly after the formation of Mehbooba Mufti's government in Jammu and Kashmir, a 21 year-old separatist fighter from Hizbul Mujahideen, Burhan Wani was gunned down along with his two associates by the Indian forces on July 8, 2016 (Dasgupta, 2016). Burhan Wani represented the fifth generation of resistance against the Indian policies in Jammu and Kashmir. He transformed the predictable form of protests by innovatively employing social media platforms. He also created a Twitter handle @Gazi_Burhan2 in 2012 and used it to disseminate pictures of atrocities carried out by the Indian forces (Pandit \& Singh, 2016). Wani's social media outreach created a stir both in the youth of Kashmir, which makes around $60 \%$ of the valley's population and in the Indian and Pakistani media. He was referred to as the poster boy of Kashmir and had a bounty of one million rupees on his arrest (Rao, 2016). Killing of Burhan Wani had an intense impact on the Valley's political, economic and security situation in terms of demonstrations by Kashmiris and longest imposed curfew by the Indian security forces. Wani relished impressive amount of support from Kashmiris both in his life and death because of four major reasons (i) armed rebels like Wani did not target civilians; (ii) they functioned independently without seeking foreign support; (iii) they choose a moderate path through welcoming Hindu pilgrims and favoring the return of migrant Kashmiri Pandits to their homes; (iv) their rebelliousness had a symbolic significance for the Kashmiri population (Geelani, 2016).The role of Kashmiri politicians in the post Burhan Wani incident grew more anti India. On the other hand the brutal policies imposed by the BJP led government in the center increased the gap between the Kashmiri public and the rest of the world. The unrest which engulfed the valley during Wani episode transformed into a devastating situation when the Indian Prime Minister Narendra Modi during his Independence Day Speech on August 15, 2019 announced his government's step to strip Kashmir from the autonomous status in terms of abrogating the Article 370 of the Indian constitution. The researcher aimed at comprehending the framing of Kashmir dispute in Pakistani and Indian media after revocation of Article 370 of the Indian Constitution. The researcher also explored the relevance of the disputed territory for the neighboring China in context of this legislative move. Kashmir for China. The study is significant from an exploratory angle as the abrogation of Article 370 has not only altered the geographical status of J\&K but has also put the stability of the whole South Asian region at an unprecedented risk. The paper also attempted to provide recommendations for improving the volatile conditions in the Kashmir valley.

\section{Scrapping of Article 370}

The scrapping of Article 370 was one of the major demands by the Hindu Nationalists since early 1950s. After mid-1960s only certain parts of Article 370 were left untouched which comprised of a state flag, an independent state constitution which was mostly symbolic and an autonomous penal code. Assurance of job opportunities and possession of land by the local residents was guaranteed through Article 35A which was also revoked later. Kashmiri state was primarily divided into union territories as the Indian constitution granted more authorities to the states as compared to unions (Bose, 2019). India divided Jammu and Kashmir into two federally administered territories after scrapping of Article 370. Jammu and Kashmir were merged into one territory and named after Jammu. Ladakh which bordered with China was made a separate territory (Jammu and Kashmir: India formally divides flashpoint state, 2019). The newly 
formed union territories were ruled directly from Delhi. Not only the Muslim population felt alienated and subjugated after the scrapping of Article 370 but also the Buddhist residents which were in majority in the eastern Ladakh district, felt deceived after losing their rights over job opportunities and land possession. BJP's decision to divide the J\&K in to separate federally administered territories can be regarded nothing less an undemocratic step by the Indian government (Gupta, 2019).

As Kashmir is a landlocked territory between India, Pakistan, China and Afghanistan resultantly the scrapping of article 370 rose concerns for security and peace in the South Asian region. Although China is not a South Asian country but it has deep rooted interests in the region. China is in possession of one-fifth part of the Kashmir region and also shares its border with Jammu and Kashmir. A relatively strong Pakistan has always been desired by China to contain India's nuclear ambitions in the region (Bukhari \& Parveen, 2014).

A clash between India and China which took place in the Ladakh region in the mid June 2020 left at least 20 Indian soldiers dead. India asserted that China has violated the agreement to abide by the Line of Actual Control (LAC) in the Galwan Valley. India also blamed China for deploying a large number of troops in the Galwan Valley and of occupying 38,000 sq. km of India's territory in the Ladakh region. The boundary disputes between India and China failed to reach a consensus despite repeated round of talks during the last 30 years. A war was also fought between India and China in 1962 in which India suffered huge losses. Clashes also erupted in 2017 when China attempted to outspread a border road. The year 2020 was considered to be more violent as the Galwan Valley clashes which were battled with clubs and sticks instead of guns played a significant role in rising tensions between India and China ("IndiaChina clash: 20 Indian troops killed in Ladakh fighting”, 2020).

Human Rights conditions were deplorable in J\&K even in 2016 when Burhan Wani's death was followed by anti-Indian riots across the valley. Curfew was forced in all districts of the valley on $15^{\text {th }}$ July 2016 which continued for 53 consecutive days and was lifted on $31^{\text {st }}$ August but was re-imposed the next day (Khurshid, 2017). During the curfew mobile and internet services were also shut down. Clashes between protestors and Indian Occupational Forces (IOF) resulted in the death of more than 150 people, injuring more than 16000 and blinding more than 150 (Khurshid, 2017). Wani aftermath brought life for the Kashmiris to the worst brink that they had witnessed during the last two decades. Routine in the valley was severely hampered as the business, transport and educational institutions were shut down for the longest period. Funerals of the killed Kashmiris lead to further clashes between the forces and protestors. The use of pellet guns by the security forces caused serious injuries to the protestors. The photographs of pellet ridden children and women stimulated an international reaction against the atrocities of Indian government in Kashmir as over 1000 people sustained eye injuries ("Jammu and Kashmir: Three months, 1,000 eye injuries by pellets", 2016). According to the Standard Operating Procedure legs are targeted in acute volatile conditions but in case of rallies held in Kashmir more than $90 \%$ received injuries above waist (Sultan, 2016). According to Human Rights Watch the condition of Human Rights the state of human rights violations intensified after the abrogation of article 370 as "Hundreds of people remain detained without charge, critics are threatened with arrest, and access to the internet is limited" (Tanzeem, 2020). The intensification of violence and human rights violations in the Indian Administered Kashmir can never be analyzed in isolation as the whole region is affected by the volatility of the decades old conflict.

\section{Peace and War Journalism}

Agenda setting has provided great theoretical support to war and peace journalism and effects studies. Framing which is seen as second level of agenda setting refers to the procedure of consolidating a news story thematically and accurately to convey the main agenda of story (Maslog et al, 2006). Entman (1993) defined framing as the selection and projection of certain aspects of the perceived reality which in turn helps in making specific causal interpretations of the reality more dominant and popular. Tankard (1991) also focused on media frames and defined them as the dominant organizing idea for 
content which provides a context through the use of selection, emphasis, exclusion and elaboration. Frames consist of main ideas, stock phrases and different visuals to facilitate a specific analysis. It is the recurrence and prominence of the texts and images with in a frame which makes the dominant interpretation more acceptable than other available options (ibid). Framing of news stories also influence audience members' perceptions of the social reality (Khan \& Yousafzai, 2005).

The taxonomy of peace and war journalism also took language in to consideration as negative wording in terms of victimizing and persecuting are discouraged in peace journalism. Peace journalism encouraged a reconciliation based advocacy approach in conflict reporting not only through news stories but also through opinion writing. Peace Journalism also focused on highlighting less visible effects of violence and emphasizing on common grounds instead of focusing on retaliation and differences (Maslog, Lee \& Kim, 2006, p.23).

Framing of War Journalism flourished on apparent effects of conflict, it is propaganda-oriented with regard to revealing others' lies and hiding ours', it only presents opinions of elite and depicts victory over the enemy as the final end (Galtung \& Fisher, 2013). Framing of Peace journalism, on the other hand is expected to be peace - oriented in terms of stipulating conflict construction and preventing conflict, truthoriented in terms of illuminating untruths of all sides, people-oriented in terms of covering people as negotiators and peace makers, and solution-oriented in terms of highlighting peace and solution initiatives (Lynch \& McGoldrick, 2005).

Lynch \& McGoldrick presented peace journalism as a larger, more rational, and precise method of covering conflicts (Maslog et al, 2006). Peace journalism is largely dependent on reporters and editors' choices regarding selection and reporting of stories which in turn develop prospects for society to reflect on non-violent reactions to conflict. According to Lynch \& McGoldrick (2005, p.5) peace journalism can be interpreted as a way of conceptual and practical apparatuses envisioned to train journalists; as it is possible for reporters to become an element of conflict resolution (Siddiqua,2018). McGoldrick and Lynch (2000) classified Galtung's ideas into 17 practices of peace journalism. The practices included focus on presenting solutions, reporting on lasting effects, angling people in news stories, searching mutual grounds for resolution, reporting on all possible sides of the story, and using accurate language.

The study attempted to answer the following Research Questions (RQ):

RQ1.How the Kashmir conflict was framed by the Indian and Pakistani media in the post Article 370 scenario?

RQ2- What is the geo strategic relevance of Jammu and Kashmir for China?

\section{Methodology}

The method of content analysis was employed to answer the first research question which was aimed at comprehending the framing patterns of Kashmir conflict in the Pakistani and Indian media. The editorials and columns published in Dawn (Pakistani media) and Daily Times of India (Indian media) were selected for the purpose of content analysis. Editorials and columns published after the scrapping of article 370 were selected for the study. Editorials and columns published from November 30, 2019 to November 30, 2020 in Dawn and Times of India retrieved from the e paper websites of the two selected dailies. A total of 118 editorials and columns were retrieved from the websites of the two dailies. All the selected editorials and columns i.e, the total population was made part of the content analysis $(\mathrm{N}=118)$. Out of the total sample 60 editorials and columns were retrieved from Dawn and 58 from Times of India. A coding sheet was developed for the purpose of the content analysis which was based on the Gultung's (1986, 1989) classification of peace and war journalism (Appendix).

Every individual editorial and column was considered as the unit of analysis for the study. Two independent coders were engaged for the study at hand. The inter coder reliability test (Hostli's formula) 
conducted on 20 stories yielded $92 \%$ or more than $92 \%$ agreement for all the frames. The second research question regarding the geo strategic relevance of Kashmir conflict for China was explored in the light of the available literature.

\section{Results \& Discussion}

RQ1.How the Kashmir conflict was framed by the Indian and Pakistani media in the post Article 370 scenario?

Table 01: Difference of War Framing in Indian and Pakistani media

\begin{tabular}{lll}
\hline War Frames & $\begin{array}{l}\text { Dawn } \\
\text { (Total Frames) }\end{array}$ & Times of India \\
\hline $\begin{array}{l}\text { Visible effects of } \\
\text { war }\end{array}$ & $52(12.94 \%)$ & $60(13.05 \%)$ \\
\hline $\begin{array}{l}\text { Differences } \\
\text { Oriented }\end{array}$ & $40(9.95 \%)$ & $46(10.00 \%)$ \\
\hline Elite oriented & $55(13.68 \%)$ & $50(10.87 \%)$ \\
\hline Here and now & $42(10.45 \%)$ & $46(10.00 \%)$ \\
\hline Dichotomy & $43(10.69 \%)$ & $58(12.61 \%)$ \\
\hline $\begin{array}{l}\text { Two-party } \\
\text { Orientation }\end{array}$ & $42(10.45 \%)$ & $46(10.00 \%)$ \\
\hline Partisan & $38(8.15 \%)$ & $48(10.43 \%)$ \\
\hline $\begin{array}{l}\text { Zero-sum } \\
\text { oriented }\end{array}$ & $40(9.95 \%)$ & $48(10.43 \%)$ \\
\hline $\begin{array}{l}\text { Uses } \\
\text { demonizing }\end{array}$ & $50(12.44 \%)$ & $58(12.61 \%)$ \\
Language & & \\
\hline $\begin{array}{l}\text { Total } \\
\text { N }(\%)\end{array}$ & $402(74.44 \%)$ & $460(88.12 \%)$ \\
\hline
\end{tabular}

Note. Chi square $=18.521 ; \overline{\mathrm{df}=8 ; p<0.05}$

The results of the content analysis showed that war framing was more frequently employed by the Indian and Pakistani media while covering Kashmir conflict after the scrapping of Article 370. Table 01 illustrates that Times of India took a lead in war framing with $88.12 \%$ of its editorials and columns dominated with war journalism frames whereas $74.44 \%$ editorials and columns in Dawn were dominated with war framing.

Table 02

Difference of Peace framing in Indian and Pakistani media

\begin{tabular}{lll}
\hline Peace Frames & Dawn & Times of India \\
\hline $\begin{array}{l}\text { Invisible effects } \\
\text { of war }\end{array}$ & $12(8.69 \%)$ & $10(16.13 \%)$ \\
\hline $\begin{array}{l}\text { Solution } \\
\text { Oriented }\end{array}$ & $6(4.34 \%)$ & $6(9.68 \%)$ \\
\hline People Oriented & $15(10.87 \%)$ & $7(11.29 \%)$ \\
\hline $\begin{array}{l}\text { Causes and } \\
\text { Consequences }\end{array}$ & $27(19.57 \%)$ & $12(19.35 \%)$ \\
\hline $\begin{array}{l}\text { Avoid labeling of } \\
\text { good and bad } \\
\text { guys }\end{array}$ & $18(13.04 \%)$ & $4(6.45 \%)$ \\
\hline $\begin{array}{l}\text { Multi-party } \\
\text { orientation }\end{array}$ & $14(10.14 \%)$ & $8(12.90 \%)$ \\
\hline Non-partisan & $14(10.14 \%)$ & $4(6.45 \%)$ \\
\hline $\begin{array}{l}\text { Win-win } \\
\text { orientation }\end{array}$ & $28(20.29 \%)$ & $8(12.90 \%)$ \\
\hline $\begin{array}{l}\text { Avoid } \\
\text { demonizing } \\
\text { language }\end{array}$ & $4(2.89 \%)$ & $3(4.84 \%)$ \\
\hline Total N $(\%)$ & $138(25.56 \%)$ & $62(11.88 \%)$ \\
\hline 8
\end{tabular}

Note. . Chi square $=18.83 ; \mathrm{df}=8 ; p<0.05$

Table 02 showed that peace framing was less frequently employed by the Indian and Pakistani media 
while covering Kashmir conflict. Dawn took a lead in peace journalism framing with $25.56 \%$ of its editorials and columns dominated with peace journalism frames whereas $11.88 \%$ editorials and columns in Times of India were dominated with peace journalism frames.

The study strengthened Galtung's $(1986,1998)$ classification of conflict reporting in to war and peace journalism. Results of content analysis supported the assumption that war coverage was the most highly recorded coverage pattern in both Indian and Pakistani media. Quantitative analysis further supported Lynch \& McGoldrick's (2005) explanation of war journalism with respect to revealing facts and truths related to others' and covering up ours' as majority of the analyzed stories used demonizing language. Presenting the opinions and views of elite and reporting conflict as a zero-sum entity were also among the frequently reported patterns of conflict coverage. The literature on peace journalism was also considerably supported as it focused on highlighting solutions, focusing on invisible effects of the conflict and covering all possible aspects of the story among other major practices (McGoldrick and Lynch 2000). Literature on framing was also rationalized by the study as media frames provided central ideas for analyzing the content by selecting, emphasizing and elaborating certain details in a contextual manner (Tankard, 1991).

\section{RQ2- What is the geo strategic relevance of Jammu and Kashmir for China?}

Kashmir conflict has been discussed time and again in the Indo-Pak context. Its relevance for the geo strategic positioning of China also needs to be explored in order to come up with more viable solutions to the world's longest running conflict. China has strategic interests in both Indian and Pakistani parts of Kashmir. The interests of China in the South Asian region have also gained momentum in lieu of its strategic alliance with both Pakistan and India. China's concerns with supporting Pakistan as a robust South Asian country are also interpreted in terms of engaging India with a strong rival for containing the latter's ambitions in the region. The silk route which helped China in maintaining strategical supremacy over India connects China to Pakistan through Kashmir. The alliance with Pakistan over Siachin is also considered to be an asset for China to overpower India from a strategical point of view (Raina, 1994). It has been argued that China supported Pakistan's nuclear ambitions to a certain extent in order to ensure that a strong ally against India is present in the region (Garver, 1992).

Although throughout the course of history China maintained a rather neutral point of view over Kashmir but at the same time it encouraged bilateral talk process between India and Pakistan, demilitarization of Siachen along with the commencement of bus service between India and Pakistan (Indo-Pak Peace Talks Seek Way Off Siachen Glacier, 2005). At the same time China has frequently rejected India's control of Jammu \& Kashmir and its declaration as integral part of India. In August 2019 the meeting of the UN Security Council took place in New York behind the closed doors. While addressing the media the Chinese Ambassador, Zhang Jun urged both India and Pakistan to "refrain from taking any unilateral action which will further aggravate" the situation (UN News, 2019).

The Indo-China 1962 border conflict helped in reshaping the bilateral relationships between Pakistan and China. Pakistan extended its support to China for securing the UN seat and in return of this favor Chinese Prime Minister offered support for Kashmir by declaring that Kashmir dispute should be resolved " in accordance with the wishes of people of Kashmir as pledged to them by India and Pakistan" (Arif, 1980). China's resolve over the Hunza Valley as a result of the 1963 agreement is considered crucial for the energy transportation purposes of China. It is through the route provided by the Pakistan administered Kashmir that the long term diplomatic and strategic interest of China in the Afghanistan region is served (Stobdan \& Chandran, 2008). The Karakorum Highway which also passes through the Pakistani administered Kashmir is vital for China as it connects Kashgar to Gilgit.

During early 1980s a shift in China's policy towards Kashmir was witnessed. It was the same era when China developed functional ties with New Delhi in order to adopt the policy of reconciliation in the whole 
of South Asia (Jain, 1989). In the post 9/11 scenario Pakistani president Pervez Musharraf visited China and expected some help from China in terms of resolving Kashmir conflict as per Pakistan's demands (PRC President Jiang Zemin Hopes for Peaceful Settlement of India-Pakistan Dispute, 2002). But Beijing maintained its neutrality position by asserting that both India and Pakistan should maintain ceasefire on the line of control and seek to resolve the conflict through mutually agreeable peaceful means (Rao, 2002).

The construction of road connections as part of China Pakistan Economic Corridor (CPEC) will also help China in accessing the important areas of the world including Persian Gulf along with acquiring access to the natural reservoirs of Pakistan (Chandran, 2013). China also seeks to maintain stability in the region as the interaction of Xinjiang and Tibet with the western markets cannot be fully explored without developing strong linkages with both India and Pakistan.

\section{Recommendations}

- The Indian government has frequently reinstated that the only problem in Kashmir conflict is the involvement of Pakistan in armed resistance; a claim which Pakistan has repeatedly declined. The Pakistani government on its side of the border has successfully cultivated an exact opposite narrative by declaring India as the chief aggressor state. The third and more rational perspective which has gained international recognition is that paramount importance should be given to the will of the Kashmiris through holding a free and fair plebiscite.

- If the Kashmir conflict is left unaddressed it can prove to be more fatal then the combined nuclear ambitions of all three states including India, China and Pakistan as the conflict has the potential to initiate a full fledge war in the region. Therefor UN needs to play an effective role in holding a fair plebiscite in the Kashmir region. United nations also need to pressurize India at both International and regional levels to reduce its military ambitions in the Indian Administered Kashmir.

- By halting all channels of possible communication between the Kashmiris and the rest of the world BJP led Indian government has deepened the mistrust and made the valley more vulnerable. The uninterrupted and unconditional provision of basic human rights facilities will help in normalizing the life for Kashmiris.

- Every incident of violence by the Indian state has provided a reason to the Kashmiris to brew their feelings of subjugation and alienation which is leading to further radicalization in the valley. In a situation like this extreme resentment can be averted by engaging local Kashmiri politicians and resuming dialogue channels for the indigenous population of Indian Administered Kashmir.

- China can play a vital role in resolving Kashmir conflict as it enjoys a strong foothold in the South Asian region and is also in a viable position to mediate fruitful bilateral talks between India and Pakistan. 


\section{References}

Arif, K. (ed). (1980). China-Pakistan Relations: 1947-1980. Lahore, PK: Vanguard Book Ltd, p.47

Bukhari, S. W. H., \& Parveen, M. T. (2014). China's approach towards Kashmir conflict: Aviable solution. Journal of Professional Research in Social Sciences, 1, 14-30.

Bose, S. (2019, Aug 13). Has India pushed Kashmir to a point of no return? BBC. Retrieved from https://www.bbc.com/news/world-asia-india 49316350

Chandran,S. (September 17, 2013). The China Rise and J\&K Analysis. Eurasia Review.

Dasgupta, P. (2016, July 11). Who Was Burhan Wani And Why Is Kashmir Mourning Him? The

Huffington Post. Retrieved from http://www.huffingtonpost.in/burhan wani/who

was burhan waniand-why is-kashmir-mourning-him

Entman RM (1993) Framing: Toward clarification of a fractured paradigm.

Fisher, D., \& Galtung, J. (2013). Pioneer of Peace Research.

Galtung, J. (1986). The green movement: A socio-historical exploration. International Sociology, 1(1), 75-90.

Galtung, J. (1989). Solving conflicts: A peace research perspective. Honolulu, HI: University of Hawaii Institute for Peace.

Garver, J. W. (1992). China and South Asia. The ANNALS of the American Academy of Political and Social Science, 519(1), 67-85.

Geelani, G. ( 2016, Sep 5). Living in the shadow of curfew in Kashmir. BBC News. Retrieved from http://www.bbc.com/news/world-asia-india-37211760

Gupta, S. (2019, Aug 17). To understand Modi's new Kashmir reality, these 5 liberal myths need to be broken. The Print. Retrieved from https://theprint.in/national interest/to understand-modis-new kashmir-reality-these-5-liberal-myths-need-to be broken/278220/

How International media covered PM Imran's powerful UN speech. (2019, Sep 28). The Express Tribune. Retrieved from https://tribune.com.pk/story/2067293/3

Indo-Pak Peace Talks Seek Way Off Siachen Glacier. (2005, May 23). Reuters

India-China clash: 20 Indian troops killed in Ladakh fighting. (2020, June 16). BBC News. Retrieved from https://www.bbc.com/news/world-asia-53061476

Jammu and Kashmir: India formally divides flashpoint. (2019). BBC News. Retrieved from https://www.bbc.com/news/world-asia-india-50233281)

Jammu and Kashmir: Three months, 1,000 eye injuries by pellets. (2016, October 13). Indian Express. Retrieved from http://indianexpress.com/article/india/india-news india/jammu kashmirpellets-burhan wani-3079819/

Jain, R. (Ed). (1989). China South Asian Relations 1949-88. New Delhi, IN: Radiant $\quad$ Publishers, $\quad$ p. 544

Jetly, R (Feb 14, 2012). Sino-Pakistan Strategic Entente: Implications for Regional Security. ISAS Working Paper 143, pp. 10-11

Yousaf, Z., Khan, S. M., \& Alvi, A. S. (2020). Media Coverage and Political Interests: Portrayal of Syrian Conflict by Saudi and Iranian Press.

Khurshid,T. (July 25, 2017). Fifth Generation Conflict in Indian Administered Kashmir (IOK). Institute of Strategic Studies .Issue Brief

Lynch, J., \& McGoldrick, A. (2005). Peace journalism: a global dialog for democracy and democratic media. Democratizing global media: One world, many struggles, 269-312.

Malik, A. (2019, August 15). Why Modi's Kashmir move is widely supported in India. BBC News. Retrieved from https://www.bbc.com/news/world-asia-india-49354697

Maslog CC, Lee ST and Kim SH (2006) Framing Analysis of a Conflict: How Newspapers in Five Asian Countries Covered the Iraq War. Asian Journal of Communication 16 (1):19-39

McGoldrick, A., \& Lynch, J. (2006, May). Peace journalism. Sri Lanka Muslim Media Forum.

Nixon, R. (1992). Seize the Moment: America's Challenge in a one-superpower World. New York. Simon and Schuster

Outrage over right-wing Euro-MPs' Kashmir visit. (2019). BBC News. Retrieved from 
https://www.bbc.com/news/world-asia-india-50231022

Pandit, S \& Singh T. A. (2016, July 9). Tech Savvy face of terror in Kashmir killed in gunfight. Times of India. Retrieved from http://timesofindia.indiatimes.com/city/srinagar/Tech-savvyface-of-terror-in Kashmir-killed-ingunfight/articleshow/53124417.cms

PRC President Jiang Zemin Hopes for Peaceful Settlement of India-Pakistan Dispute. (2002). Xinhua English. Retrieved from wnc.dialog.com.

Raina, D. (1994). Kashmir: Distortions and reality. New Delhi, IN: Reliance Publishing House.pp. 25 26

Rao, P. (2016, July 19). Online Radicalization: The Example of Burhan Wani. IDSA Issue brief. Retrieved from $\quad$ http://www.idsa.in/system/files/issuebrief/ib_online radicalisation.pdf

Siddiqua, A. (2018). Reporting Intra State Conflicts: Challenges for Mainstream Television Reporters. Journal of Research in Social Sciences, 6(1), 224-238.

Stobdan, P. \& Chandran, D.S. (2008). The Last Colony: Muzaffarabad-Gilgit-Baltistan. Jammu: Center for Strategic and Regional Studies (CSRS). University of Jammu, pp. 125-56.

Sultan, A.A. (2016, July 19). Concerns in Kashmir over police pellet guns. BBC News. Retrieved from http://www.bbc.com/news/world-asia-india-36822567

Tankard, J. W. (1991). Media frames: Approaches to conceptualization and measurement.

Tanzeem, A. (2020, August 05). One year later, Human Rights Violations Continue in Indian Kashmir. Voice of America. Retrieved from https://www.voanews.com/southcentral asia/one-year-later-human-rights violations-continue-indian-kashmir

UN News (2019) UN Security Council discusses Kashmir, China urges India and Pakistan to ease tensions, Aug 16. Available at : https://news.un.org/en/story/2019/08/1044401

Yasir, S. \& Gettleman, J. (2019, Oct 31). Anxious and Cooped Up, 1.5 Million Kashmiri Children Are Still Out of School. New York Times. Retrieved from https://www.nytimes.com/2019/10/31/world/asia/kashmir school-children.html 


\section{Appendix}

\section{Galtung's $(1986,1989)$ classification of Peace and War Journalism}

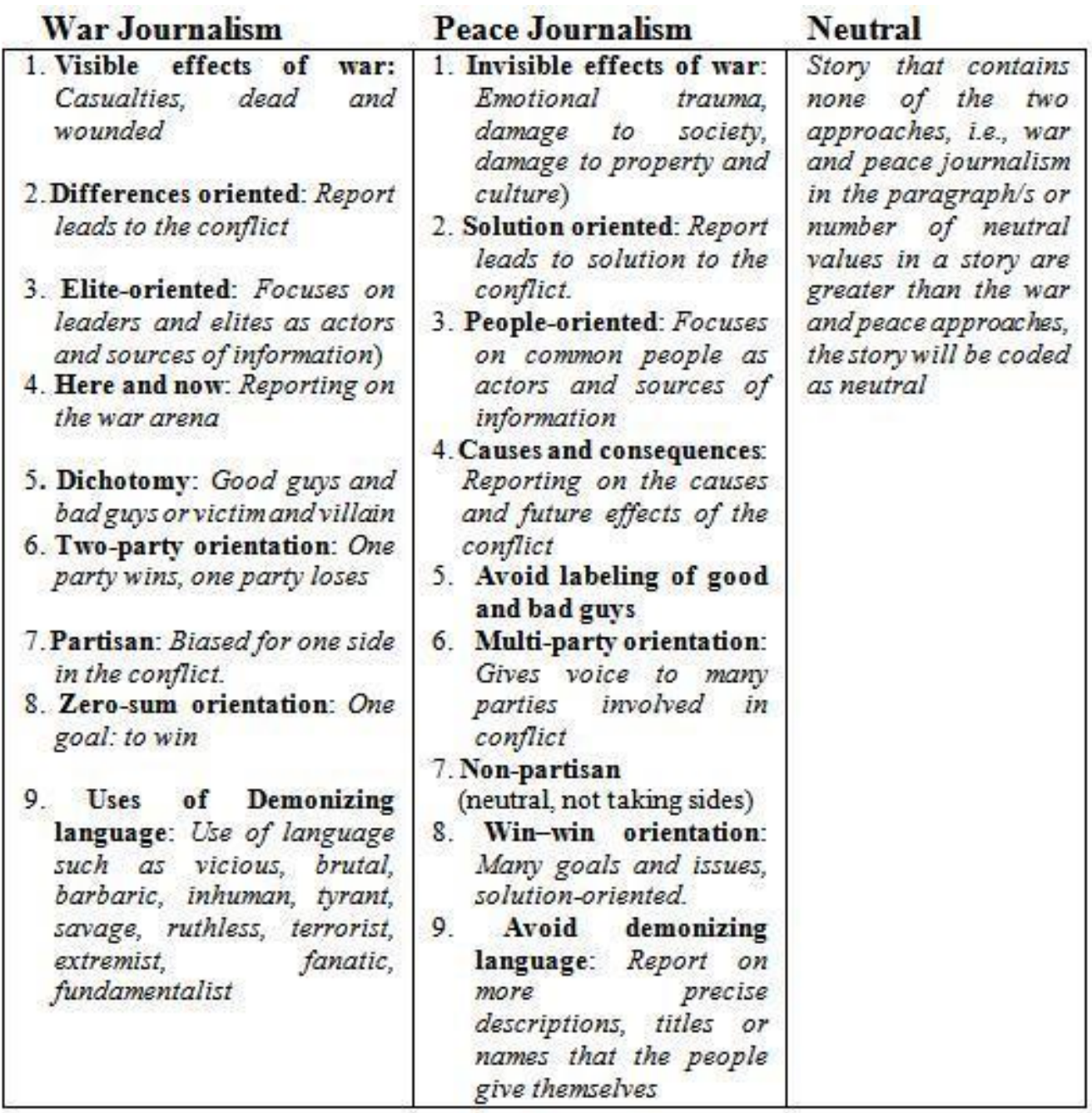

